\title{
Study on the Development of Lactic Acid Bacteria in Bread Dough Enriched with Zinc and Selenium
}

\author{
Denka Zlateva $^{1}$, Dana Stefanova ${ }^{1}$ and Nadya Ninova-Nicolova ${ }^{2}$ \\ 1. Department of Commmodity Science, Faculty of Economics, University of Economics, Varna 9000, Bulgaria \\ 2. LB Bulgaricum PLC, Research \& Development Center, Sofia 1225, Bulgaria
}

\begin{abstract}
The incorporation of lyophilized lactic acid bacteria in dough formulation is a current trend in bread making in order to achieve quality improvement and extension of shelf life of bread. Another major aspect for today's bread making industry is an increase of the biological value of bread, by addition of mineral substances that are deficient in bread (such as zinc and selenium). This is an effective approach to combat the existing mineral deficiency in population nutrition. The aim of the present study is to investigate the development of lactic acid bacteria in a medium enriched with zinc and selenium. It was found that the addition of $\mathrm{ZnSO}_{4} \cdot 7 \mathrm{H}_{2} \mathrm{O}$ in an amount of $0.174 \mathrm{~g} / \mathrm{kg}$ flour and $\mathrm{Na}_{2} \mathrm{SeO}_{3} \cdot 5 \mathrm{H}_{2} \mathrm{O}$ in an amount of $880.28 \mu \mathrm{g} / \mathrm{kg}$ flour (alone and in combination) did not inhibit the development of lactic acid bacteria used as starter cultures in bread dough formulation. It was found that the growth of the lactococcal component of the applied starters is dominant. The results reveal the possibility of obtaining bread with increased biological value and improved quality.
\end{abstract}

Key words: Bread dough, lactic acid bacteria, starter cultures, zinc, selenium.

\section{Introduction}

In recent decades, lactic acid bacterial starter cultures have been increasingly used in bread making to improve the quality and the shelf life of bread. The interest in such starter cultures is explained by the positive impact of the lactic acid micro-flora on the quality of the product-shortening the time of dough fermentation due to the more intensive acid formation and enriched aroma due to the synthesis of a wide range of aromatic substances (diacetyl, acetaldehyde, acetoin, methylglyoxal, etc.) [1].

The fact that the development of lactic acid bacteria contributes to the prolongation of bread shelf life is of particular importance as it suppresses the growth of agents causing microbiological spoilage. Plenty of authors have focused their efforts on studying the influence of lactic acid bacteria on the suppression of

Corresponding author: Denka Zlateva, associate professor, Ph.D., research fields: improving of quality, nutritional value and shelf life of food products. rope spoilage of bread by Bacillus subtilis and other species. Mentes and co-authors [2] studied the impact of Lactobacillus plantarum LMO 25 and Lactobacillus almentarius LMO 7 on Bacillus subtilis and Bacillus licheniformis and concluded that when the wheat bread formulation includes 20\% dough prepared with the above-mentioned starters, Bacillus strains were suppressed. This is due to the production of bacteriocins and their activity, especially at low $\mathrm{pH}$ values $(\mathrm{pH}<4)$.

De Muynck et al. [3] conducted research on different species and strains of lactic acid bacteria and their ability to inhibit the growth of microflora causing bread spoilage. They demonstrate the high capability of Lactobacillus acidophilus LMG 9433, Lactobacillus amylovorus DSM 20532, Lactobacillus brevis LMG 6906 and Lactobacillus coryniformis subsp. coryniformis LMG 9196 to produce substances with antimicrobial properties. Every common cause of bread spoilage is mold growth. It has been found that Lactobacillus plantarum FST 1.7 slows down the 
growth of Fusarium culmorum and Fusarium graminearum [4]. Lavermicocca and co-authors [5] investigated the growth of mold in samples of bread prepared with another strain-Lactobacillus plantarum 21B. It is proved that mold growth starts considerably later compared to the control sample without added lactic acid bacteria. This is due to phenylmaleic and p-hydroxyphenylmalonic acids formed by lactic acid bacteria.

Besides improving quality and shelf life of bread, another primary issue to which the efforts of researchers are directed is to increase its biological value.

Mineral deficiency is a problem affecting nearly 3 billion of the world population [6]. For most of the population, the necessary zinc and selenium intake is not achieved, as it is the case for some of the developed countries in Western Europe. There is evidence that zinc deficiency affects nearly $40 \%$ of the world population [7, 8]. The deficiency of zinc is the reason for $4.4 \%$ of the mortality in Africa, Asia and Latin America [9] and it may be a factor for various abnormalities and clinical manifestations.

Zinc is an essential microelement for humans. Well-known is its important role in health as a result of the wide range of biological functions it performs. Zinc is a component of over 200 enzymes that are related to the synthesis of proteins and DNA, the synthesis of hormones, and the health of the skin. The role of zinc for the development and growth of children is clearly established $[10,11]$.

Selenium is also an essential microelement with great importance for human health. It is a component of numerous enzymes that contribute to the normal course of metabolic processes, also has proven antioxidant properties. There is a strong relation between adequate selenium intake and normal thyroid function, as well as maintaining the growth of hair and nails of a person. Selenium is unevenly distributed in nature, which can lead to deficiency in some geographic areas. It has been found that approximately
100 million of the world population suffers from selenium deficiency [12].

The perceived seriousness of the problem of shortage of minerals, justifies the different countries to develop and implement programs to increase the intake of essential mineral substances through the enrichment of food products to cover the physiological needs of the human body. An effective way is to offer bread with higher biological value, as bread is a food product with high daily consumption, especially in Bulgaria, where bread consumption constitutes a major proportion of the daily meals. There is sufficient literature concerning bread enrichment with calcium, iron and magnesium [13-15], but the possibility of enrichment with zinc, and especially selenium, is of growing interest in recent years.

In our previous studies [16] the possibility of improving the biological value of wheat bread by the addition of zinc and selenium was established. For the purpose zinc sulfate heptahydrate $\left(\mathrm{ZnSO}_{4} \cdot 7 \mathrm{H}_{2} \mathrm{O}\right)$ in an amount of $0.174 \mathrm{~g} / \mathrm{kg}$ flour and sodium selenite pentahydrate $\left(\mathrm{Na}_{2} \mathrm{SeO}_{3} \cdot 5 \mathrm{H}_{2} \mathrm{O}\right)$ in an amount of 880.28 $\mu \mathrm{g} / \mathrm{kg}$ flour were used. These compounds are specifically selected as enriching suplements, as they are in a soluble and bioavailable form, absorb easily, pass through the cell membrane and participate in biochemical processes. The added quantities are calculated so that the bread achieves levels close to the recommended average daily dietary intake values that are: Zinc $11 \mathrm{mg} / \mathrm{d}$; Selenium $55 \mu \mathrm{g} / \mathrm{d}$. Their content in bread is determined by the ISP-OES method for zinc, and HG-ISP-AES method for selenium [17]. These levels are sufficient to achieve the bioavailability of $\mathrm{Zn}$ and Se in bread so that the elements mentioned above are involved in various biosyntheses in the human body.

It was proved that the use of the stated amounts of zinc and selenium salts enables bread to be obtained with an increased biological value, preserving the quality of the ready-made bread and providing 
longer-lasting freshness [18].

It is known that zinc and selenium-containing enzymes are involved in the regulation of numerous of biochemical processes in living organisms. We could assume their influence on the development of lactic acid bacteria. A number of studies on this issue have been published in recent years [19-21]. Mogna et al. [22] explore approaches to improve the biological digestibility of zinc and selenium in the human body. For this purpose, they use Lactobacillus buchneri Lb26 (DSM 16341) and Bifidobacterium lactis Bb1 (DSM 17850) as carriers of bio-accessible zinc and selenium. Calomme et al. [23] establish the relation between the lactic acid bacteria population and the concentration of selenium in the environment in which they develop. The authors also identify the possibility of Lactobacillus delbrueckii subsp. bulgaricus to retain ions of zinc, copper, manganese, iron. A study was conducted on laboratory mouse of which diet includes lactic acid bacteria enriched with zinc and selenium in a specific ratio. It has been found that the animals receiving the additive raise the levels of zinc and selenium in the blood plasma, increase the activity of some enzymes (glutathione peroxidase, etc.) and increase the total antioxidant capacity [24].

Pophaly et al. [25] investigated the conditions for the development of lactic acid bacteria in a medium enriched with inorganic selenium for the purpose of converting it into organic form and its subsequent use for food supplementation to enhance its biological value. Ren and co-authors [26] study the possibility of obtaining zinc and selenium-enriched probiotic preparations and their effect on serum levels of zinc and selenium in the organism, as well as on the intestinal micro-flora. At the present stage, there is a growing interest in the enrichment of foods with zinc and selenium with simultaneous use of lyophilized lactic acid bacterial starter cultures.

The aim of this study is to investigate the possibility for development of lactic acid bacteria starter cultures for bread making in a medium containing zinc and selenium needed for enrichment of bread to achieve the recommended average daily intakes.

\section{Materials and Methods}

\subsection{Materials}

Wheat dough preparation

The dough was composed by $250.00 \mathrm{~g}$ of wheat flour type 500, $130.00 \mathrm{~cm}^{3}$ water, certain amounts of yeast ( $0.9 \%$ of the flour weight) and salt ( $1.3 \%$ of the flour weight ). The dough was prepared in two-phase method. Initially a sample of $100 \mathrm{~g}$ flour and water in a ratio of 1:1 was prepared. During the kneading of dough lyophilized lactic acid starter cultures were added as follows:

- Starter culture BR Z1, containing: Lactococcus lactis ssp. lactis, Lactococcus lactis ssp. cremoris, Lactococcus lactis ssp. lactis var. diacetylactis, Leuconostoc mesenteroides ssp. cremoris, Lactobacillus delbrueckii ssp. bulgaricus, Streptococcus thermophilus;

- Starter culture BR Z3, containing: Lactococcus lactis ssp. lactis, Lactococcus lactis ssp. cremoris, Lactococcus lactis ssp. lactis var. diacetylactis, Leuconostoc mesenteroides ssp. cremoris, Streptococcus thermophilus.

Starter cultures were produced in lyophilized form by the Starter Culture Laboratory of LB Bulgaricum PLC (Sofia, Bulgaria). The amount for use was $70 \mathrm{~g}$ per $100 \mathrm{~kg}$ of flour, such as without prior activation of starter cultures.

After the kneading the dough fermentation was performed in fermentation chamber at $37{ }^{\circ} \mathrm{C}$ for 6 hours. Than the bread dough was kneaded with the addition of the other ingredients according to the bread formulation. The bread dough matures $50 \mathrm{~min}$ at $38-39^{\circ} \mathrm{C}$, such as on the 25 minutes it is re-knead.

In order to increase the bread biological value in the formulation chemically pure mineral salts, namely: zinc sulphate heptahydrate $\left(\mathrm{ZnSO}_{4} \cdot 7 \mathrm{H}_{2} \mathrm{O}\right)$ in an amount of $17.4 \mathrm{~g} / 100 \mathrm{~kg}$ of flour and sodium selenite pentahydrate $\left(\mathrm{Na}_{2} \mathrm{SeO}_{3} \cdot 5 \mathrm{H}_{2} \mathrm{O}\right)$ in an amount of 88,028 
mg/100 kg flour, manufactured by Merck, Germany, were also added. The amounts of added mineral substances were calculated to reach the dietary intake reference of the population in Bulgaria, which are 11 $\mathrm{mg} / \mathrm{d}$ for zinc and for selenium of $55 \mu \mathrm{g} / \mathrm{d}$. The calculated amounts of $\mathrm{ZnSO}_{4} \cdot 7 \mathrm{H}_{2} \mathrm{O}$ and $\mathrm{Na}_{2} \mathrm{SeO}_{3} \cdot 5 \mathrm{H}_{2} \mathrm{O}$ were dissolved in the water for the dough kneading.

The subject of the study was to identify isolates of lactic acid bacteria obtained after fermentation of the dough for $6 \mathrm{~h}$. For the purpose of the present study, samples of the following composition (Table 1) were tested.

\subsection{Methods}

For the characterization and identification of lactic acid bacteria, classical and modern molecular methods were used. The methods of analysis and the individual steps were as follows:

- Morphological and cultural methods

Cellular and colonial morphology

The description of the cellular and colonial morphology of the isolated strains of lactic acid bacteria was performed by microscope observation of smears on a slide, as well as monitoring colonies developed on a solid sterile medium (M17 agar).

- Molecular-genetic methods

Isolation of total DNA

Isolation of total DNA was performed by the method of Delley et al. [27].

\section{$P C R$ reactions and visualization}

The species affiliation of lactic acid bacteria was determined by performing ARDRA (Amplified Ribosomal DNA Restriction Analysis) method [28] that is based on 16S-rDNA PCR amplification, digestion with suitable restriction enzymes and gel electrophoresis of the resulting fragments.

\subsection{Statistical Analysis}

Measurement scores were subjected to analysis of variance (ANOVA). Statistical analyses were conducted at a significance level of $\alpha=0.05$.

\section{Results and Discussion}

In order to test the ability of lactic acid bacteria from the starter cultures to grow in a medium supplemented with zinc and selenium, morphological and microscope examinations were conducted. The results obtained are presented in Table 2. Lactic acid bacteria were identified by their shape, color, size of the colonies and cell morphology. The bacteria isolated from dough samples formed milky white colonies with regular circular shape with flat ends (S), sharply convex smooth surface and were larger than $1.5 \mathrm{~mm}$. When viewed under a microscope the cells appeared as oval cocci arranged singly and in groups. The established morphology shows their affiliation with the genus Lactococcus.

Table 1 Formulation of the samples tested.

\begin{tabular}{|c|c|c|c|c|c|c|}
\hline \multirow[b]{2}{*}{ Sample } & \multicolumn{6}{|c|}{ Bread dough formulation ingredients } \\
\hline & Flour & Water & $\begin{array}{l}\text { Starter culture } \\
\text { BR Z1 }\end{array}$ & $\begin{array}{l}\text { Starter culture } \\
\text { BR Z3 }\end{array}$ & $\mathrm{ZnSO}_{4} \cdot 7 \mathrm{H}_{2} \mathrm{O}$ & $\mathrm{Na}_{2} \mathrm{SeO}_{3} \cdot 5 \mathrm{H}_{2} \mathrm{O}$ \\
\hline Sample №1 & + & + & + & - & - & - \\
\hline Sample №2 & + & + & + & - & + & \\
\hline Sample №3 & + & + & + & - & - & + \\
\hline Sample №4 & + & + & + & - & + & + \\
\hline Sample №5 & + & + & - & + & - & - \\
\hline Sample №6 & + & + & - & + & + & - \\
\hline Sample №7 & + & + & - & + & - & + \\
\hline Sample №8 & + & + & - & + & + & + \\
\hline
\end{tabular}

"+" indicates the ingredients that are included in the formulation of the respective sample;

“-” indicates ingredients that are not included in the formulation. 
Table 2 Characterization and cellular morphology of the investigated lactic acid bacteria.

\begin{tabular}{|c|c|c|c|c|c|c|}
\hline \multirow[b]{2}{*}{ Sample } & \multirow[b]{2}{*}{ Total number, cfu/mL } & \multicolumn{3}{|c|}{ Colonial characteristics } & \multicolumn{2}{|c|}{ Cellular morphology } \\
\hline & & $\begin{array}{l}\text { Size } \\
\mathrm{L} / \mathrm{M} / \mathrm{S}\end{array}$ & Color & $\begin{array}{l}\text { Type of shape } \\
\text { R/S }\end{array}$ & $\begin{array}{l}\text { Microscopic } \\
\text { observation }\end{array}$ & Identification \\
\hline Sample №1 & $2.6 \times 10^{9}$ & $\mathrm{~L}$ & White & S & Oval cocci & Lactococcus lactis \\
\hline Sample №2 & $1.6 \times 10^{8}$ & $\mathrm{~L}$ & White & $S$ & Oval cocci & Lactococcus lactis \\
\hline Sample №3 & $1.5 \times 10^{8}$ & $\mathrm{~L}$ & White & $S$ & Oval cocci & Lactococcus lactis \\
\hline Sample №4 & $4.3 \times 10^{8}$ & $\mathrm{~L}$ & White & S & Oval cocci & Lactococcus lactis \\
\hline Sample №5 & $1.0 \times 10^{8}$ & $\mathrm{~L}$ & White & S & Oval cocci & Lactococcus lactis \\
\hline Sample №6 & $2.0 \times 10^{8}$ & $\mathrm{~L}$ & White & S & Oval cocci & Lactococcus lactis \\
\hline Sample №7 & $1.8 \times 10^{8}$ & $\mathrm{~L}$ & White & S & Oval cocci & Lactococcus lactis \\
\hline Sample №8 & $1.9 \times 10^{9}$ & $\mathrm{~L}$ & White & S & Oval cocci & Lactococcus lactis \\
\hline
\end{tabular}

Size: L > 1.5 mm; M $0.5 \div 1.5 \mathrm{~mm}$; $\mathrm{S}<0.5 \mathrm{~mm}$.

Type of shape: R-irregular form; S-round shape with equal ends.

The results from total viable counts after six-hour fermentation showed growth of the starter culture in all samples (Table 2). At the end of dough maturation, the total counts were in the order of $10^{8}-10^{9} \mathrm{cfu} / \mathrm{mL}$, while the baseline concentration of the microorganisms was about $10^{6} \mathrm{cfu} / \mathrm{mL}$.

The results showed that in Sample №1, consisting of flour, water and starter culture BR Z1, the total number of emerged microorganisms was $2.6 \times 10^{9}$ cfu/mL. When $\mathrm{ZnSO}_{4} \cdot 7 \mathrm{H}_{2} \mathrm{O}$ and $\mathrm{Na}_{2} \mathrm{SeO}_{3} \cdot 5 \mathrm{H}_{2} \mathrm{O}$ (Sample №4) were simultaneously added to the sample, the total number of lactic acid bacteria increased considerably compared to that found in samples with the two mineral substances added separately. In Sample №5, prepared with starter culture BR Z3, the total number of emerged lactic acid bacteria was $1.0 \times 10^{8} \mathrm{cfu} / \mathrm{mL}$. From the results obtained, it appeared that lactic acid bacteria in the starter culture composition were favorably influenced by the presence of the added mineral salts. This is clearly evident from the results obtained in determining their total number in the presence of $\mathrm{ZnSO}_{4} \cdot 7 \mathrm{H}_{2} \mathrm{O}$ (Sample №6)—2.0 $\times 10^{8} \mathrm{cfu} / \mathrm{mL}$. Relative values were also obtained for the Sample №7, which included $\mathrm{Na}_{2} \mathrm{SeO}_{3} \cdot 5 \mathrm{H}_{2} \mathrm{O}-1.8 \times 10^{8} \mathrm{cfu} / \mathrm{mL}$. These data are in correlation with Peñas et al. [29], who find that in low concentration as used in this research, selenium has a beneficial effect on the development of lactic acid bacteria. In an other study
Xi et al. [30] have obtained results which lead to similar conclusions.

An increase in the total number of lactic acid bacteria was observed in Sample №8, in addition to which the two mineral salts $\left(\mathrm{ZnSO}_{4} \cdot 7 \mathrm{H}_{2} \mathrm{O}\right.$ and $\mathrm{Na}_{2} \mathrm{SeO}_{3} \cdot 5 \mathrm{H}_{2} \mathrm{O}$ ) were added. The total number found was $1.9 \times 10^{9} \mathrm{cfu} / \mathrm{mL}$, i.e., reported to increase by an order of magnitude of the total number of lactic acid microorganisms. This is probably due to the synergistic effect that is found between the components of the composition. To confirm the microscopic results and for determining the affiliation of the isolated lactic acid bacteria, the samples were subjected to ARDRA analysis.

The results from the ARDRA analysis showed that under the specified conditions lactic acid bacteria that grew in sour dough were predominantly from the Lactococcus lactis species. Further analysis with species-specific PCR by the Nomura method [31] confirmed that all isolates belonged to the Lactococcus lactis ssp. lactis subspecies. For this purpose, electrophoresis was performed to determine the Lactococcus lactis ssp. lactis and Lactococcus lactis ssp. cremoris. The results are presented in Fig. 1.

The results of the electrophoretic studies confirm the results of the visual tests. It was found that in this composition of the starter cultures and these culture conditions rapid development of lactococcal components is reported, and in particular-of the Lactococcus lactis 


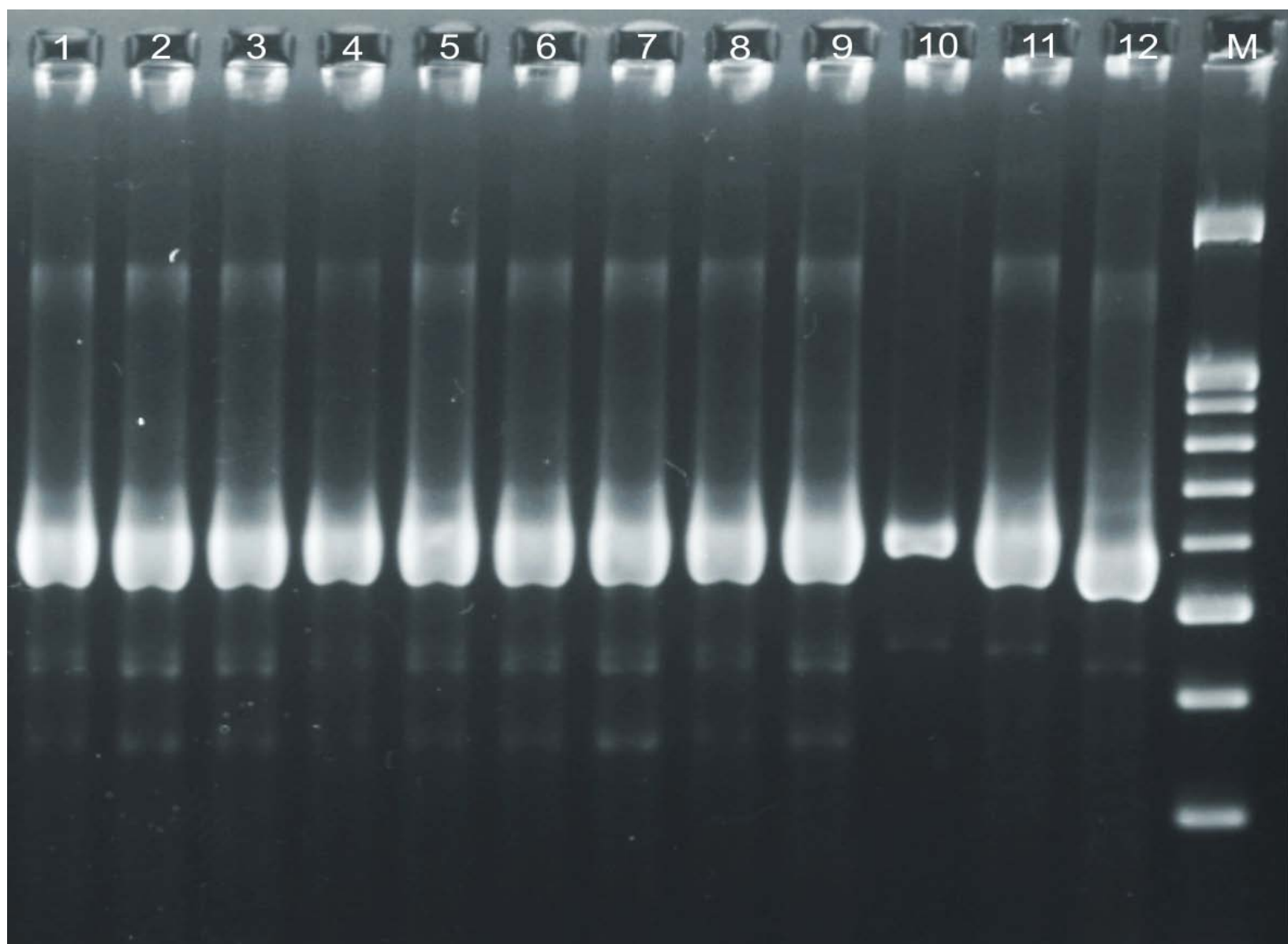

Fig. 1 Electrophoretic separation and visualization of products obtained by species-specific PCR by the Nomura method. Positions: 1-10-PCR products; 11-Lactococcus lactis ssp. lactis; 12—Lactococcus lactis ssp. cremoris; M-Molecular weight marker.

ssp. lactis. This demonstrates that lactic acid bacteria of the starter cultures used for bread making can be successfully grown in the presence of inorganic zinc and selenium compounds- $\mathrm{ZnSO}_{4} \cdot 7 \mathrm{H}_{2} \mathrm{O}$ and $\mathrm{Na}_{2} \mathrm{SeO}_{3} \cdot 5 \mathrm{H}_{2} \mathrm{O}$.

\section{Conclusions}

From the results obtained, it can be concluded that the addition of mineral salts containing $\mathrm{Zn}$ and Se (alone and in combination) in amounts provided for enhancing the biological value of the bread, does not inhibit the development of lactic acid bacteria in the composition of the starter cultures. It was proved that in a medium with an increased content of zinc and selenium, the lactococcal component of lactic acid starter cultures used for bakery production is most vigorously developed. This reveals the possibility of simultaneous use of zinc and selenium containing mineral salts, and lyophilized lactic acid starter cultures to increase the biological value of bread and prolong its shelf life.

\section{Acknowledgement}

The authors would like to thank to Starter Culture Laboratory of LB Bulgaricum PLC and University of Economics-Varna for the support.

\section{References}

[1] Plessas, A., Alexopoulos, I., Mantzourani, A. et al. 2011. "Application of Novel Starter Cultures for Sourdough Bread Production.” Anaerobe 17: 486-9.

[2] Menteş, Ö., Ercan, R., and Akçelik, M. 2007. "Inhibitor Activities of Two Lactobacillus Strains, Isolated from 
Sourdough, against Rope-Forming Bacillus Strains.” Food Control 18: 359-63.

[3] De Muynck, C., Annelies, J., Leroy, S., et al. 2004. "Potential of Selected Lactic Acid Bacteria to Produce Food Compatible Antifungal Metabolites.” Microbiological Research 159: 339-46.

[4] Dal Bello, F., Clarke, C., Ryan, L., et al. 2007. "Improvement of the Quality and Shelf Life of Wheat Bread by Fermentation with the Antifungal Strain Lactobacillus Plantarum FST 1.7.” Journal of Cereal Science 45: 309-18.

[5] Lavermicocca, P., Valerio, F., Evidente, A., Lazzaroni, S., Corsetti, A., and Gobbetti, M. 2000. "Purification and Characterization of Novel Antifungal Compounds from the Sourdough Lactobacillus Plantarum Strain 21B.” Applied and Env. Microbiology 66: 4084-90.

[6] Souza, G., Hart, J., Carvalo, J., et al. 2014. “Genotypic Variation of Zinc and Selenium Concentration in Grains of Brazilian Wheat Lines.” Plant Science 224: 27-35.

[7] Maret, W., and Sandstead, H. H. 2006. "Zinc Requirements and the Risks and Benefits of Zinc Supplementation." Journal of Trace Elements in Medicine and Biology 20 (1): 3-18.

[8] Prasad, A. S. 2014. "Zinc in Humans: Health Disorders and Therapeutic Effects.” Microelements in Medicine 15 (1): 3-12.

[9] Liberato, S. C., Singh, G., and Mulholland, K. 2015. "Zinc Supplementation in Young Children: A Review of the Literature Focusing on Diarrhoea Prevention and Treatment.” Clinical Nutrition 34 (2): 181-8.

[10] Prasad, A. S. 2014. "Impact of the Discovery of Human Zinc Deficiency on Health.” Journal of Trace Elements in Medicine and Biology 28 (4): 357-63.

[11] Salgueiro, M. J., Zubillaga, M. B., Lysionek, A. E., Caro, R. A., Weill, R., and Boccio, J. R. 2002. "The Role of Zinc in the Growth and Development of Children." Nutrition 18 (6): 510-9.

[12] Bañuelos, G., Lin, Z.-Q., and Yin. X. 2014. Selenium in the Environment and Human Health. London: Taylor \& Francis Group.

[13] Votinova, E. 2008. "Study of the Effect of Calcium-Containing Additives on the Consumer Properties of Bakery Products of a Functional Purpose.” PhD thesis, Kemerovo.

[14] Iserliyska, D. 2000. "Study and Development of Technology for Obtaining Bread Enriched with Mineral Elements.” PhD thesis, Plovdiv.

[15] Fik, M., Surówka, K., Maciejaszek, I., Macura, M., and Michalczyk, M. 2012. "Quality and Shelf Life of Calcium-Enriched Wholemeal Bread Stored in a Modified Atmosphere.” Journal of Cereal Science 56: 418-24.

[16] Zlateva, D., and Stefanova, D. 2016. "Enhancing the
Nutritional Value of Bread through Fortification with Zinc and Selenium.” 20th IGWT Symposium, Commodity Science in a Chanching World. September 2016, Varna, Bulgaria, 553-9.

[17] Iliev, A., and Yovkova, D. 2013. "ICP-AES-HG Method for Determination of Trace Amount of Selenium in Foodstuff." Scientific Works of University of Food Technologies LX: 662-5.

[18] Stefanova, D., Zlateva, D., and Chochkov, R. 2016. "Shelf Life of Zinc- and Selenium-Enriched Wheat Bread." Scientific Works of University of Food Technologies 63 (1): 71-5.

[19] Alzate, A., Fernández, A., Pérez-Conde, C., Gutiérrez, M., and Cámara, C. 2008. "Comparison of Biotransformation of Inorganic Selenium by Lactobacillus and Saccharomyces in Lactic Fermentation Process of Yogurt and Kefir.” J. Agric Food Chem. 56 (18): 8728-36.

[20] Chen, L., Pan, D., Zhou, J., and Jiang, Y. 2005. "Protective Effect of Selenium-Enriched Lactobacillus on $\mathrm{CCl}_{4}$-Induced Liver Injury in Mice and Its Possible Mechanisms.” World J. Gastroenterol 11 (37): 5795-800.

[21] Krittaphol, W., Wescombe, A., Thomson, D., McDowell, A., Tagg, R., and Fawcett, P. 2011. "Metabolism of L-Selenomethionine and Selenite by Probiotic Bacteria: In Vitro and in Vivo Studies.” Biol Trace Elem Res. 144 (1-3): 1358-69.

[22] Mogna, L., Nicola, S., Pane, M., Lorenzini, P., Strozzi, G., and Mogna, G. 2012. "Selenium and Zinc Internalized by Lactobacillus Buchneri Lb26 (DSM 16341) and Bifidobacterium Lactis Bb1 (DSM 17850): Improved Bioavailability Using a New Biological Approach.” Journal of Clinical Gastroenterology 46: 41-5.

[23] Calomme, M., Branden, K., and Berghe, D. 1995. "Selenium and Lactobacillus Species." Journal of Applied Microbiology 79 (3): 331-40.

[24] Ren, Z., Zhao, Z., Wang, Y., and Huang, K. 2011. "Preparation of Selenium/Zinc-Enriched Probiotics and Their Effect on Blood Selenium and Zinc Concentrations, Antioxidant Capacities, and Intestinal Micro-flora in Canine.” Biological Trace Element Research 141 (1): 170-83.

[25] Pophaly, S., Poonam, Singh, P., Kumar, H., Tomar, S. K., and Singh, R. 2014. "Selenium Enrichment of Lactic Acid Bacteria and Bifidobacteria: A Functional Food Perspective." Trends in Food Science \& Technology 39 (2): 135-45.

[26] Ren, Z., Zhao, Z., Wang, Y., and Huang, K. 2011. "Preparation of Selenium/Zinc-Enriched Probiotics and Their Effect on Blood Selenium and Zinc Concentrations, Antioxidant Capacities, and Intestinal Micro-flora in Canine.” Biological Trace Element Research 141 (1): 170-83. 
[27] Delley, M., Mollet, B., and Hottinger, H. 1990. “DNA Probe for Lactobacillus Delbrueckii.” Applied and Environmental Microbiology 56: 1967-70.

[28] Weisburg, W., Barns, S., Pelletier, D., and Lane, D. 1991. "16 S Ribosomal DNA Amplification for Phylogenetic Study.” Journal of Bacteriology 173 (2): 697-730.

[29] Peñas, E., Villaluenga, C., Frias, J., Martínez, M., Corona, M., Madrid, Y., Cámara, C., and Valverde, C. 2012. "Se Improves Indole Glucosinolate Hydrolysis Products Content, Se-Methylselenocysteine Content, Antioxidant
Capacity and Potential Anti-inflammatory Properties of Sauerkraut.” Food Chemistry 132 (2): 907-14.

[30] Xi, L., Yi, L., Jun, W., Huigang, L., and Songsheng, Q. 2002. "Microcalorimetric Study of Staphylococcus aureus Growth Affected by Selenium Compounds." Thermochimica Acta. 387 (1): 57-61.

[31] Nomura, M., Kobayashi, M., and Okamoto, T. 2002. "Rapid PCR-Based Method Which Can Determine Both Phenotype and Genotype of Lactococcus lactis subspecies.” Appl Environ Microbiol 68 (5): 2209-13. 